klusion, nemlig at bogen Ricoeur - en bermenentisk brobygger, i alt væsentligt og som dens redaktører gerne ser det, vil være anvendelig både som en af flere grundbøger i faget videnskabsteori, ligesom den formentlig vil være et kærkomment oplæg til diskussion inden for såvel humaniora som samfundsvidenskaberne.

Jens Viggo Nielsen

\section{Ideer dræber}

Jens-Martin Eriksen \& Frederik Stjernfelt, Hadets anatomi. Rejser i Bosnien og Serbien, Lindhardt \& Ringhof, 2003, 332 sider, $299 \mathrm{kr}$.

Det moderne vestlige liberale liv bliver ofte beskyldt for at være uheroisk og kedeligt. Det liberale menneske er svagt, egoistisk og ikke parat til at ofre sig for noget. Det liberale samfund mangler eventyr og mandsmod. Den liberale modsætnings: dragningen mod det store, det sublime, det voldsomme, offeret, kampen er derfor dens fortrængte underside. JensMartin Eriksen og Frederik Stjernfelt har i de seneste år foretaget en række rejser $\mathrm{i}$ et (tidligere) land, der $\mathrm{i}$ den grad har mærket dragningens magt. Hadets anatomi er, som undertitlen siger, 'rejser i Bosnien og Serbien', men det er også rejser i det sociales vilkår og farer. Eriksen og Stjernfelt har rejst rundt og interviewet en lang række af aktive og observerende aktører i den jugoslaviske tragedie i forsøget på at forstå mekanismerne bag iscenesættelsen og udførelsen af et folkemord. Hvad de foretager, er en vivisektion, en opskæring af et levende had; selv i dag efter alle mordene, alle tragedierne, venter Balkan på den næste krig.

I bogen er der et interview med sociologiprofessoren Bozidar Jaksic, hvori han siger: "Men min drøm er, at vi engang vil begynde at blive et kedeligt land. Lige nu er vi interessante som tigre eller andre eksotiske dyr i zoologisk have. Men jeg vil hellere kigge fra den anden side af tremmerne. Vi burde leve kedelige liv ligesom I gør i Danmark." (s.144-5). Leve kedelige liv? Hvordan kan man ønske det?

Francis Fukuyama er inde på det samme i den desværre alt for lidt diskuterede afslutning på sin Historiens afslutning og det sidste menneske, hvor han diskuterer det liberale menneskes jagt efter det ubestemmelige mere, der giver livet fylde, der bringer blodet til at bruse. Tilværelsen i det liberale samfund tilfredsstiller ikke helt. Det efterlader en længsel efter noget mere ophøjet, noget mere farefuldt end det borgerlige liv.

Hadets anatomi er i høj grad en undersøgelse af denne længsel, der greb det tidligere Jugoslavien. Hvorfor begyndte tidligere naboer og venner at dræbe hinanden? Hvordan blev et sådant had mobiliseret? Bogen er en undersøgelse af de intellektuelle forarbejder bag et folkemord. Hvordan opildne befolkningsgrupper imod hinanden? Hvordan gøre et slag, der 
fandt sted på Solsortesletten i 1389, til et virksomt element i det nutidige? Hvordan knytte løsrevne fragmenter af forklaringer, myter, historier og begivenheder sammen til én lang fortælling om forfølgelse og had?

Hvordan får en biologiprofessor (senere præsident for Republika Srpska og nu fængslet i Haag for krigsforbrydelser), Biljana Plazsic, sig selv til at sige: "Det var et genetisk deformt materiale, der tiljublede Islam. Og selvfølgelig bliver dette gen nu simpelthen mere koncentreret i hver efterfølgende generation. Det bliver værre og værre, det udtrykker simpelthen sig selv og dikterer deres måde at tænke og opføre sig på. Det ligger i deres gener." (s.76). Den mest spændende og bærende del af bogen er forsøget på at forstå orkestreringen af folkemordet. Som de konkluderer i afslutningen: "hadets anatomi er sammensat af nutidige kræfter, ikke af mystisk 'ældgammelt had'. ... Hadet breder sig fra den politiske top og ud i befolkningen" (s.257, 258).

$\mathrm{Og}$ der er tætte forbindelser mellem den politiske og den intellektuelle top. Bogen er et stykke detektivarbejde omkring udarbejdelsen og udbredelsen af et memorandum i 1986 fra det Serbiske Akademi for Videnskab og Kunst, som de i 1991 kalder for et "nationalt program for det serbiske folks march ind i fremtiden”. Det bliver en støvlebeklædt march ind i tragedien anført af Milosevic men hjulpet på vej af utallige. Dette memorandum spiller en aldrig fuldt ud belyst rolle $\mathrm{i}$ den politiske mobilisering til folkemordet ved at fremstille serberne som forfulgte og undertrykte, men med en historisk ret og forpligtelse til et Storserbien. Der er også diskussion af det bosniske modstykke, nemlig Izetbegovic' islamiske deklaration fra 1970.

Ideer kan dræbe. Og ideer kan skjule drab. En forstemmende del af bogen er de mange, der i dag ikke indser og som direkte benægter folkemordene. De samme aktører, der var aktive i forberedelsen og udførelsen af folkemordene, er nu i gang med at benægte dem som optakt til de næste.

Der er også i bogen en diskussion af det, Eriksen og Stjernfelt kalder en dansk folkemordsbenægter, nemlig slavisten Per Jacobsen fra Københavns Universitet, der igen ifølge Eriksen og Stjernfelt har spillet en aktiv rolle som benægter af serbernes folkemord $\mathrm{i}$ den danske offentlighed. Denne diskussion er siden blevet ført i forskellige medier herunder en kronik i Jyllandsposten d.19. februar. Først tvivler man: kan man virkelig benægte de serbiske massakrer og krigsforbrydelser? Så får fortvivlelsen kraft: hvordan kan et veluddannet, oplyst, universitetsuddannet og -ansat (!) menneske benægte folkemord? Og så skammer man sig efter at have tænkt: hvordan kan en dansker benægte folkemord? I denne opgivenhed over menneskets, potentielt ethvert menneskes uanset baggrund, nationalitet, opdragelse, 
stilling etc. forfaldenhed til selektiv blindhed forstår man først folkemordets tragedie: at vi alle er forfaldne til de stereotyper, der gør et folkemord muligt.

Det er ikke uoplyste og barbariske menneskers dumhed. Det er din nabo og dig selv i blodig konflikt. Det største problem med at forstå radikaliteten af dette er afværgemekanismen: alle andre end mig og mine. Efter læsningen af Hadets anatomi og efter drabet på Zoran Djindic henfalder man let til stereotypen om den balkanske syge; om de af naturen krigeriske balkanere specielt serberne. Djindic og Kostunica er kun marginalt bedre end Milosevic og Karadzic; alle venter bare på den næste chance til at realisere deres storserbiske eller storbosniske projekt. Ingen har lært noget. Alle bruger krigene til at retfærdiggøre og afstive deres egen omverdensforståelse. Godt at vi er trådt ind $i$ den postmoderne, posthistoriske fredstilstand her i det mætte Vesten ...

'Der bliver aldrig fred.' 'De har altid dræbt hinanden.' Alle disse (halv)forklaringer vi let trækker frem for (ikke rigtig) at forstå og for at distancere os, er del af den præcis samme mekanisme, som skaber nok distance mellem mennesker til at, som Richard Rorty siger, vi ikke længere kan se dem som en del af et 'os', men derimod som et truende 'dem', vi hellere må dræbe, før de dræber os, eller som vi hellere må ignorere, så længe som muligt ('lad dem slagte hinanden så længe de ikke flygter op til os').

Det er en god bog om et fascinerende emne, men man skal ikke gå til den med ønsket om at få et overblik over krigene og aktørerne i det tidligere Jugoslavien. Navne og begivenheder flyver rundt uden forsøg på at knytte dem sammen. Interviews og rejsebeskrivelser, forklaringsforsøg og småfilosoferen afløser hinanden. På et tidspunkt begynder irritationen at melde sig. Ophobningen af løsrevne fakta og påstande fra interviewpersonerne mangler en sammenhæng at forstås indenfor. Det forsøger de at råde bod på med det afsluttende essay 'Fremtidens spejl', der desværre henfalder til resten af bogens fragmentariske uorden. Her tages en mængde spændende diskussioner om had, nationalisme, multikulturalisme, det politiskes natur, statens opløsning, intellektuelles ansvar etc. op uden at det bliver til meget mere end antydninger. Synd, for Eriksen og Stjernfelt har tydeligvis noget at ville sige. Og noget, jeg gerne ville have læst meget mere af.

Mikekel Thorup

\section{En indføring $\mathrm{i}$ et hånd- værk \\ Sebastian Olden-Jorgensen: Til kilderne, Gads Forlag 2001, 129 kr.}

I historieskrivningens nyere historie har kildekritikken levet en noget omtumlet tilværelse. Da historiedisci- 